\title{
PENGARUH VARIASI MAIN JET NOZZEL PADA SISTEM KARBURATOR TERHADAP UNJUK KERJA MESIN
}

\author{
Alvinsen Alfonso ${ }^{1)}$, Abrar Riza ${ }^{2)}$ dan I Made Kartika Dhiputra ${ }^{3)}$ \\ Program Studi Teknik Mesin Universitas Tarumanagara, Jakarta \\ e-mail: alvinsenalfonso27@gmail.com
}

\begin{abstract}
This study discusses the effect of variations in the diameter of the main jet nozzles on the performance of the motor fuel. Performance analysis covering torque, power and specific fuel consumption $(s f)$. With the aim to determine the maximum performance that can be generated on any variation of the diameter of the main jet nozzles. At the time of this experiment performed with the engine 4 stroke Honda GX-160, using hydro tool dynamometer and using premium fuel. The data taken is the engine rotation, the force measured on the dynamometer and the time spent fuels. Tests conducted at the Laboratory of Energy Conversion Mechanical Engineering UNTAR Jakarta. Testing is done by providing the machine with a load variation of rotation remains in order to obtain a force on each spin machine with a main jet nozzle diameter variations. Variations rev the engine starts at the minimum rotation until maksimuml with fixed load, variations in the diameter of the main jet nozzles on testing.
\end{abstract}

Keywords: main jet nozzles, the performance of the motor fuel, dynamometer

\section{PENDAHULUAN}

Pada saat ini motor bakar merupakan mesin yang sering dijumpai dan digunakan pada berbagai keperluan untuk membantu kebutuhan manusia seperti keperluan transportasi, pemakaian rumah tangga dan industri. Motor bakar adalah salah satu jenis dari mesin konversi energi yang mengubah energi termal untuk melakukan kerja mekanik atau mengubah tenaga kimia bahan bakar menjadi tenaga mekanis. Energi pada motor bakar diperoleh dari proses pembakaran bahan bakar dikonversikan menjadi energi mekanik, yang kemudian energi mekanik ini yang akan dimanfaatkan untuk proses tertentu.

Pada dasarnya energi dari motor bakar tidak bisa langsung dimanfaatkan jika tidak dihubungkan pada mesin atau alat tertentu. Dalam pemilihan suatu motor bakar haruslah disesuaikan dengan kebutuhan alat yang akan dihubungkan pada motor bakar tersebut. Jika yang dibutuhkan tenaga misalnya untuk ngangkut beban, tentulah torsi dari motor bakar yang dibutuhkan. Jika yang dibutuhkan kecepatan, maka daya dari motor bakar yang dibutuhkan. Oleh sebab itu, sebagai parameter pemilihan yaitu dengan cara mengetahui performa dari mesin motor bakar yang akan dipilih. Parameter tesebut dapat berupa torsi, daya, dan konsumsi bahan bakar dari motor bakar tersebut. Jika tidak memperhatikan aspek tersebut, maka pada pengoprasian motor bakar akan tidak efisien bahkan akan mengakibatkan kerusakan baik dari motor bakar tersebut ataupun mesin yang akan dihubungkan.

Kelebihan: Lebih hemat bahan bakar, Tidak menggunakan oli samping sehingga lebih ekonomis, Tenaga yang dihasilkan besar dan stabil, sehingga memiliki akselerasi yang baik pada medan pegunungan atau jalan menanjak, Asap yang dihasilkan dari proses pembakaran (relative) tidak ada atau ramah lingkungan.

Banyak faktor yang mempengaruhi peforma motor bakar seperti posisi jarak celah elektroda busi, campuran bahan bakar dan masih ada cara lain yang mempengaruhi performa suatu motor bakar. Busi berfungsi untuk membakar campuran udara bensin yang telah dimampatkan dengan jalan memberi loncatan api listrik diantara kedua elektrodanya. Karena itu motor bensin dinamai dengan spark ignitions. Sedangkan karburator adalah tempat bercampurnya udara dan bensin. Campuran tersebut kemudian masuk ke dalam silinder yang dinyalakan oleh loncatan bunga api listrik dari busi menjelang akhir langkah kompresi. Salah satu cara faktor yang mempengaruhi peforma motor bakar selain yang telah disebutkan sebelumnya, yaitu nosel atau pilot jet. Fungsi nosel adalah pengabutan bahan bakar atau ada yang menyebut dengan Injektor. Disebut injector karena tugas dari komponen ini adalah menginjeksi, dan disebut pengabut karena bahan bakar 
keluar dari komponen ini dalam bentuk kabut, sedangkan disebut nosel karena ujung komponen ini luas penampang semakin mengecil. Dari hal tersebut bisa dilihat pada kondisi nosel yang berbeda akan mengakibatkan perbedaan berapa persen motor bakar dapat mengeluarkan daya dan torsi maksimal serta dapat dilihat juga berapa nilai konsumsi bahan bakar pada setiap variasi nosel pada pengujian. Berdasarkan latar belakang tersebut, maka penulis mengambil skripsi dengan judul : Pengaruh Variasi Main Jet Nozzel Pada Sistem Karburator Terhadap Unjuk Kerja Mesin.

\section{PERUMUSAN MASALAH}

Melakukan pengujian untuk mengetahui apakah nosel GX140 dan GX200 memiliki pengaruh yang baik terhadap performa motor bakar yang lebih baik bila dibandingkan dengan menggunakan nosel GX160. Dengan perbedaan diameter nosel dimana diameter nosel GX140 lebih kecil dari GX160 lebih kecil dari GX200.

Batasan masalah dalam penelitian ini hanya membahas

a. Pada penelitian ini dilakukan pada motor bakar 4 langkah, volume silinder 160 cc dengan menggunakan motor Honda GX 160.

b. Bahan bakar yang digunakan hanya menggunakan bahan bakar bensin (Premium) dengan menggunakan labu ukur yang ber volume $8 \mathrm{~mL}$.

c. Parameter pengukuran peforma motor bakar yang diamati meliputi torsi, daya dan konsumsi bahan bakar spesifik (sfc).

d. Pengambilan data pada putaran 1300, 1700, 2100, 2500, 2900, 3300, dan 3700.

e. Pada penelitian ini hanya meneliti nosel dari variasi nosel GX140, GX160, dan GX200.

\section{KAJIAN PUSTAKA}

Motor bensin empat tak adalah termasuk dalam jenis motor pembakaran dalam (Internal Combustion Engine) yang bahan bakar bensin sebagai bahan bakar. Pada motor bensin, bahan bakar bensin dibakar untuk memperoleh tenaga, kemudian tenaga ini diubah menjadi tenaga gerak oleh suatu mekanisme tertentu yang dapat menggerakkan mobil. Pada motor bensin empat langkah, torak bergerak bolak balik di dalam silinder. Titik terjauh (atas) yang dapat dicapai oleh piston tersebut dinamakan Titik Mati Atas (TMA), sedangkan titik terdekat disebut (bawah) Titik Mati Bawah (TMB).

Pada siklus ideal, diasumsikan fluida kerjanya hanya udara sebagai gas ideal yang kalor spesifiknya konstan. Pada proses langkah kerja seperti langkah hisap dan buang diasumsikan terjadi pada tekanan konstan. Untuk langkah kompresi dan tenaga dianggap pada keadaan adiabatik. Pada siklus ini kalor diperoleh dari sumber kalor dan tidak ada proses penyalaan (tidak ada reaksi 6 kimia). Siklus udara pada motor bakar yang sering dijumpai adalah siklus otto, siklus disel dan siklus gabungan.

Siklus otto ini sering disebut juga siklus dengan siklus ledakan, hal ini dikarenakan proses pembakaran terjadi sangat cepat sehingga menyebabkan peningkatan tekanan yang tiba-tiba. Pada siklus ini penyalaan pada proses pembakaran dibantu dengan loncata bunga api. Untuk lebih jelas proses yang terjadi pada siklus ini bisa dilihat pada diagram p-v pada Gambar 1 [3].

Adapun urutan prosesnya adalah sebagai berikut :

- Langkah isap (0-1) merupakan proses tekanan konstan.

- Langkah kompresi (1-2) merupakan proses adiabatik.

- Proses pembakaran volume konstan(2-3) dianggap sebagai proses pemasukan kalor pada volume kostan.

- Langkah kerja (3-4) merupakan proses adiabatik proses pembuangan kalor

- Proses pelepasan kalor (4-1) dianggap sebagai proses pengeluaran kalor pada volume konstan .

- Langkah buang (1-0) merupakan proses tekanan konstan, gas pembakaran dibuang lewat katup buang. 

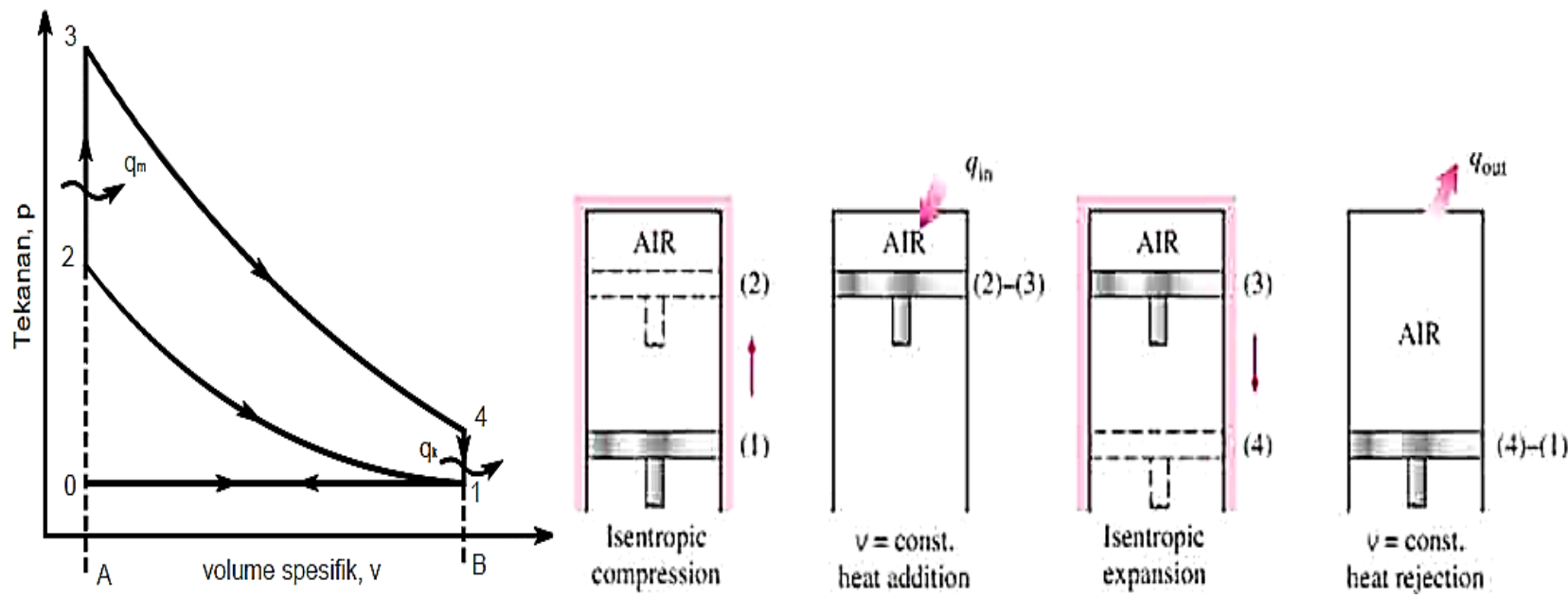

Gambar 1. Siklus ideal mesin otto [3]

Pada siklus aktual pada mesin otto fluida kerja sesuai dengan kejadian secara aktualnya, yaitu campuran bahan bakar dan udara. Pada siklus ini kalor merupakan hasil dari proses pembakaran. Untuk langkah hisap tekanan lebih rendah dibanding dengan langkah buang. Proses kompresi dan ekspansi tidak pada kondisi adiabatis karena pada proses ini terdapat kerugian panas. Proses pembakaran dari penyalaan busi sampai akhir pembakaran. Untuk lebih jelas bisa dilihat diagram p-v di bawah ini.
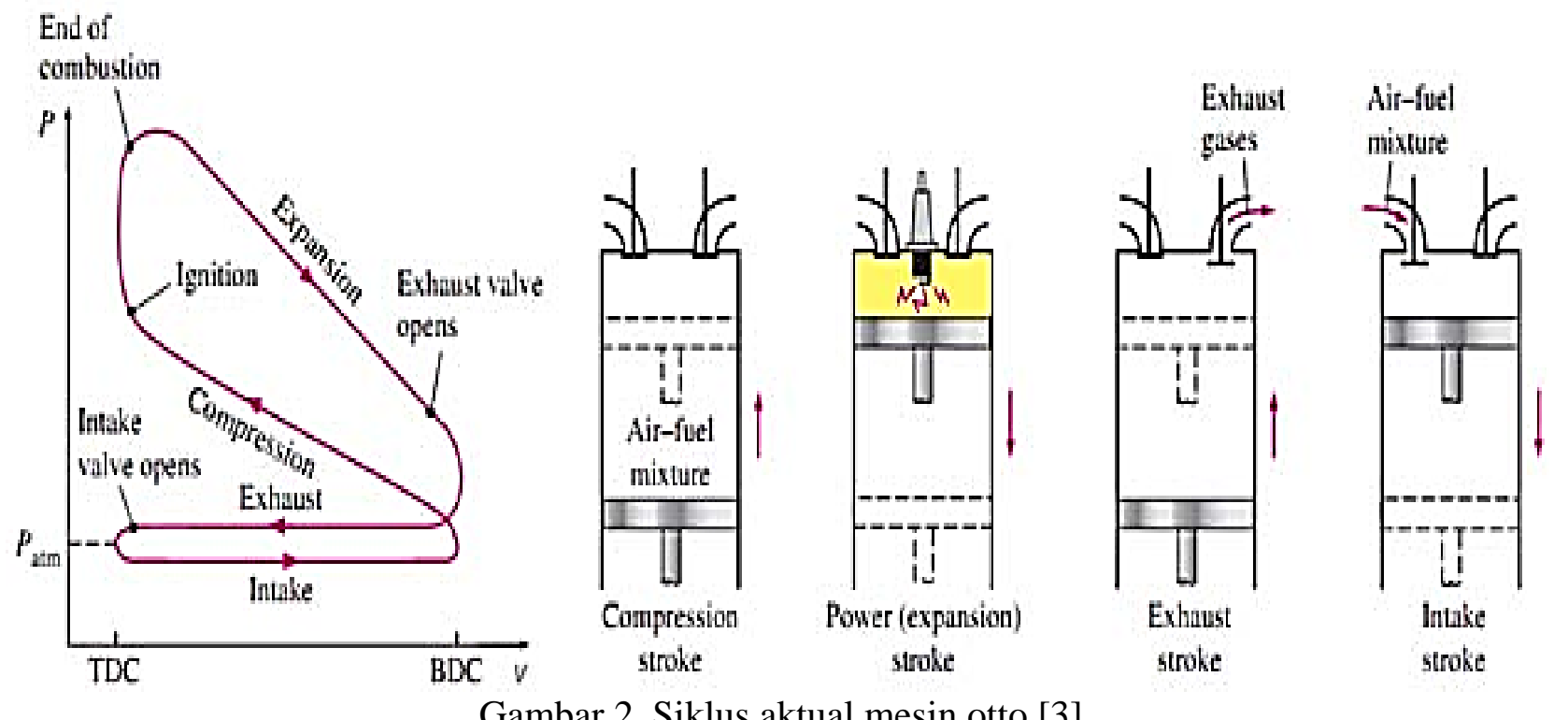

Gambar 2. Siklus aktual mesin otto [3]

Motor bensin empat tak adalah termasuk dalam jenis motor pembakaran dalam (Internal Combustion Engine) yang bahan bakar bensin sebagai bahan bakar. Pada motor bensin, bahan bakar bensin dibakar untuk memperoleh tenaga, kemudian tenaga ini diubah menjadi tenaga gerak oleh suatu mekanisme tertentu yang dapat menggerakkan mobil. Pada motor bensin empat langkah, torak bergerak bolak balik di dalam silinder. Titik terjauh (atas) yang dapat dicapai oleh piston tersebut dinamakan Titik Mati Atas (TMA), sedangkan titik terdekat disebut (bawah) Titik Mati Bawah (TMB). 


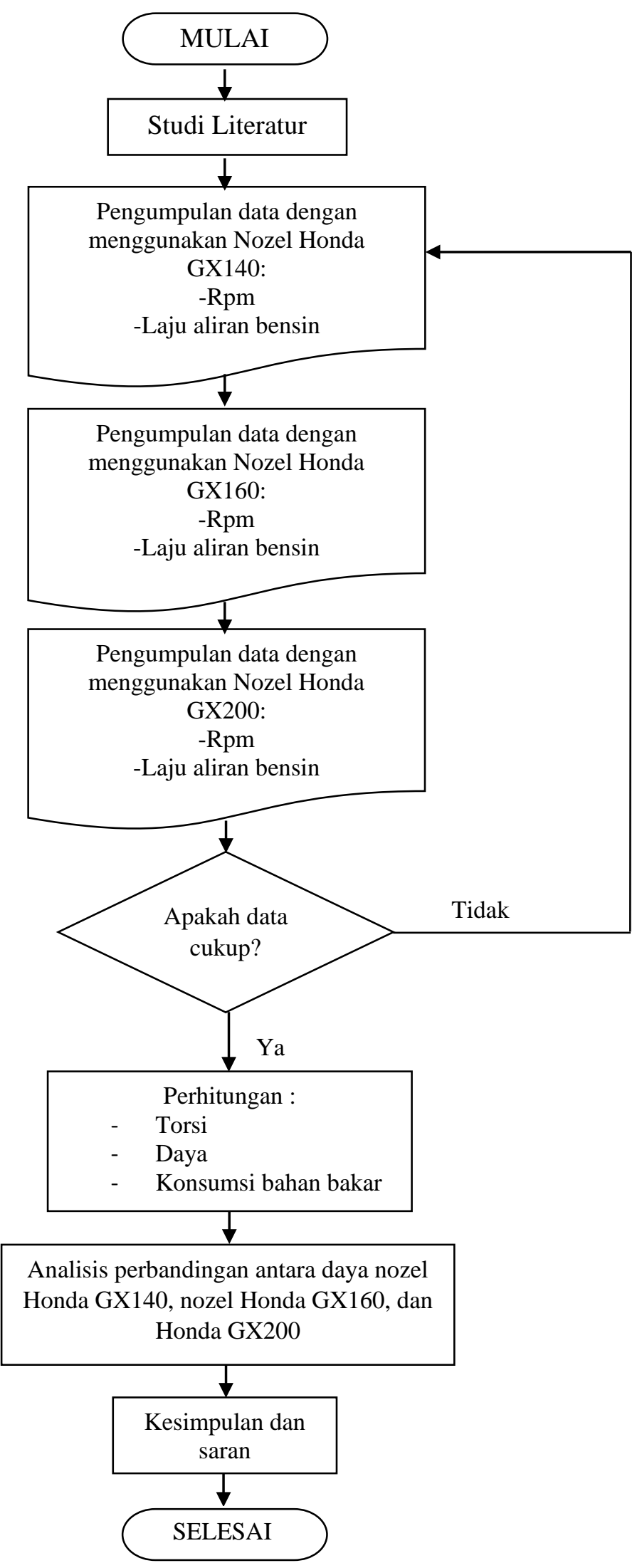

Gambar 3. Diagram Alir Penelitian. 
Pada penelitian atau eksperimen ini, dilakukan di Laboratorium Prestasi Mesin Jurusan Teknik Mesin Universitas Tarumanagara.

Dalam penelitian ini alat dan bahan yang digunakan adalah : bahan yang di gunakan adalah karburator dan air. Alat yang digunakan adalah mesin motor bakar 4 langkah dengan 1 silinder. Dimana pada mesin motor bakar ini memiliki beberapa komponen yaitu : labu ukur, tangki bensin, forcemeter, tachometer, dan termokopel, busi, stopwatch.

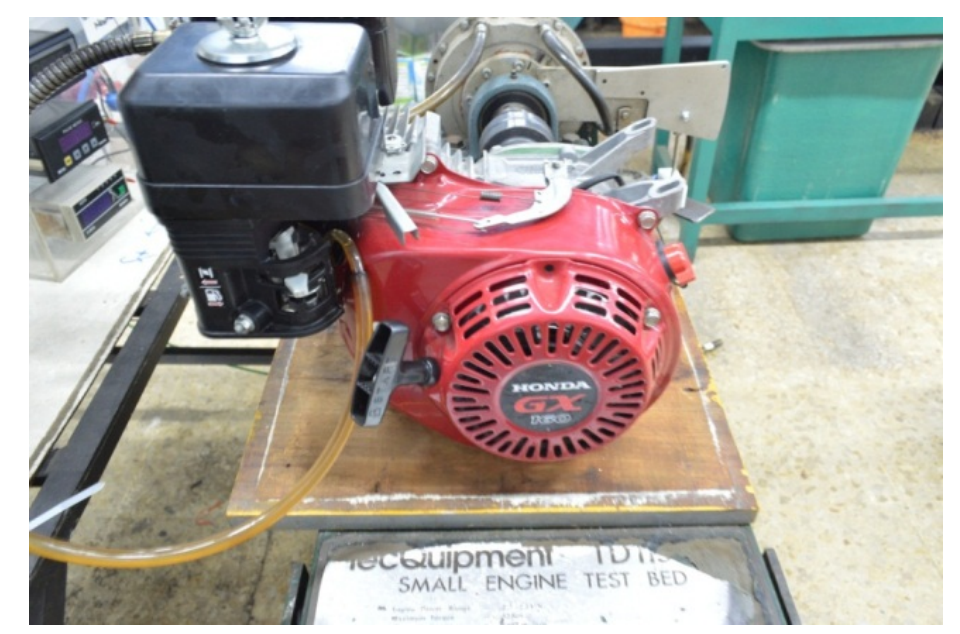

Gambar 4. Mesin Motor Bakar

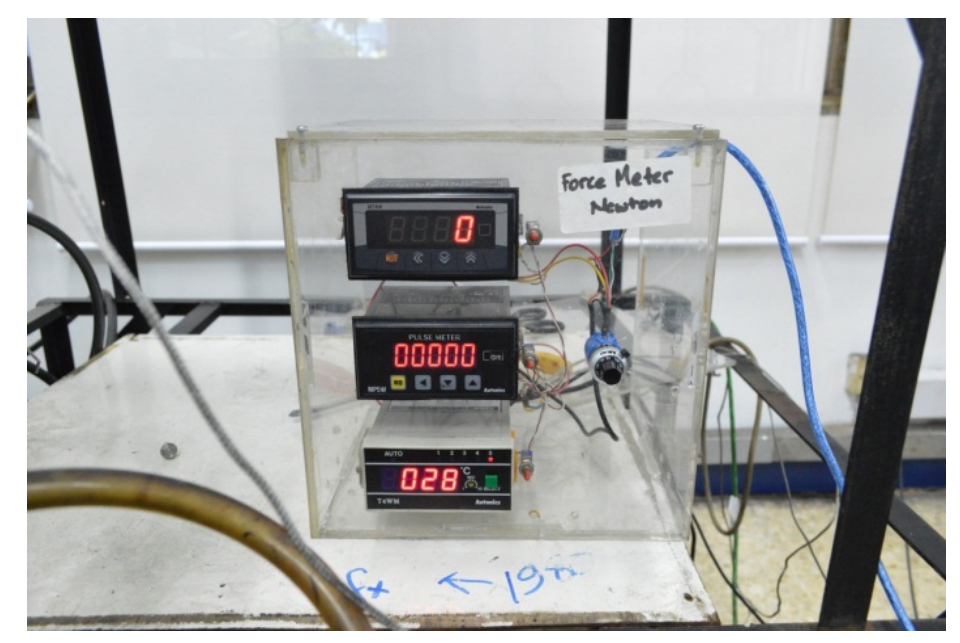

Gambar 5. Forcemeter, Tachometer, dan Termokopel

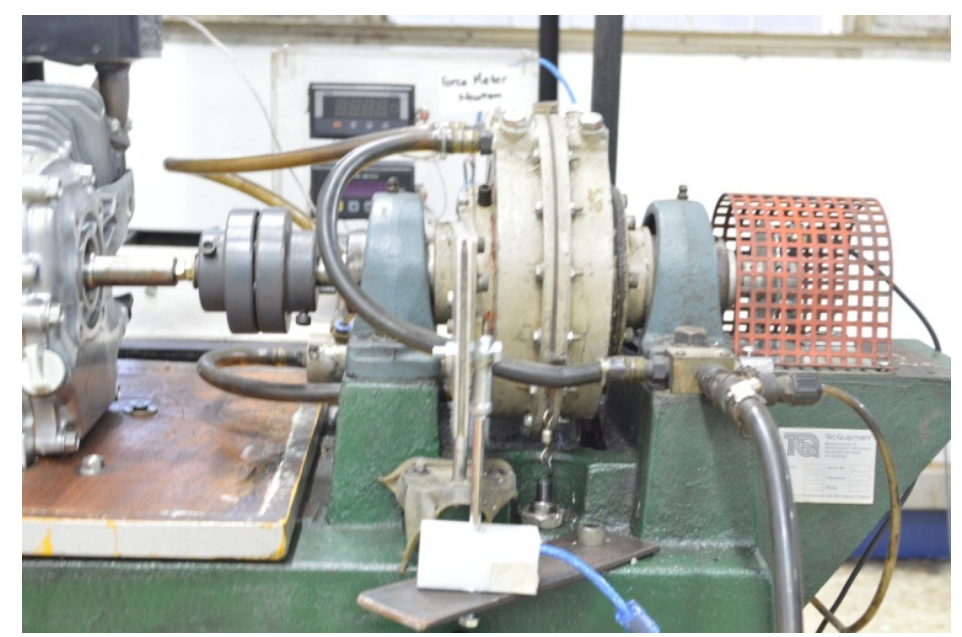

Gambar 6. Hydraulic Dynamometer 


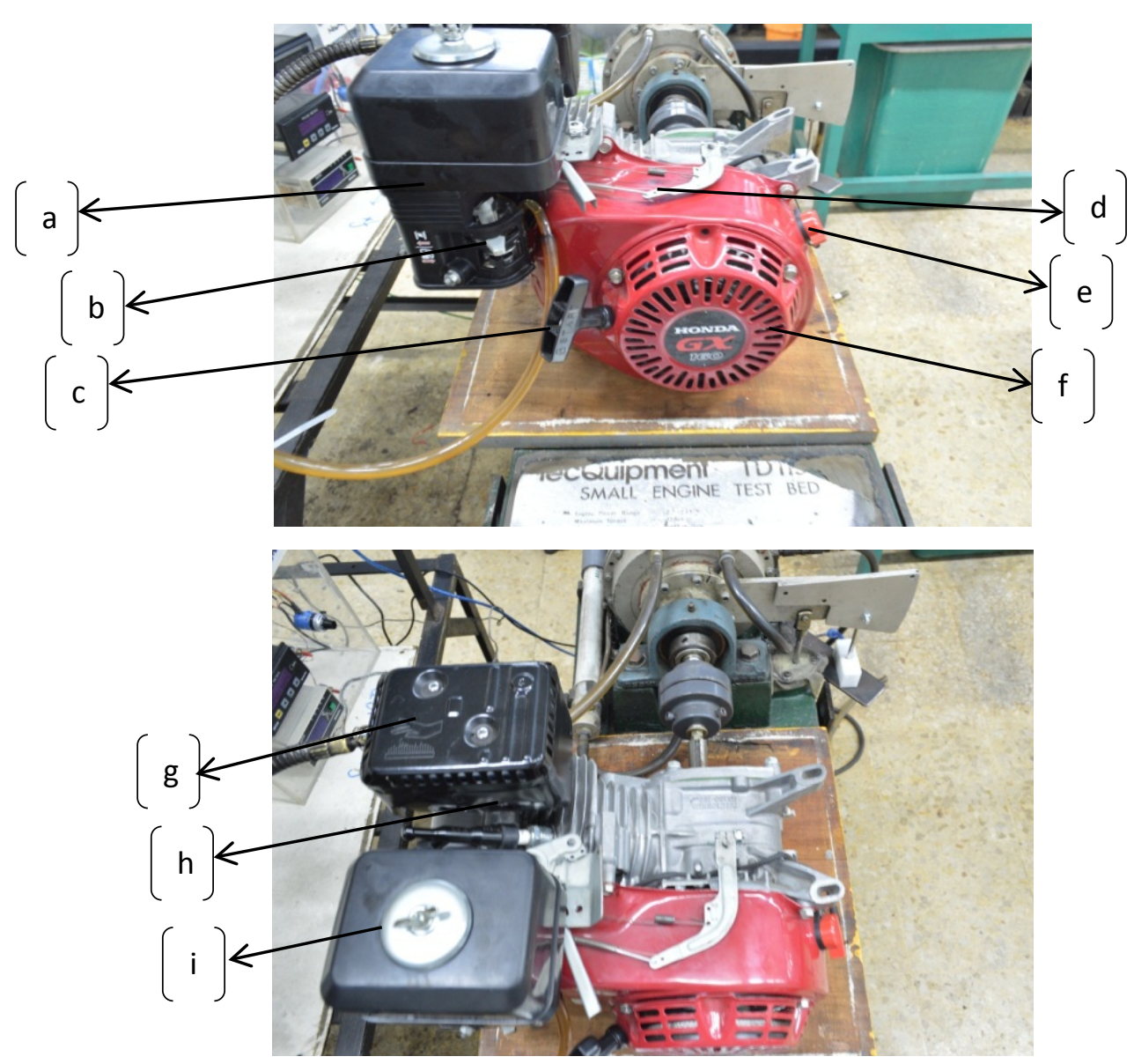

Gambar 7. Komponen pada Mesin Utama
a. Choke Lever
b. Fuel Valve
c. Starter Grip
d. Throttle Lever
e. Engine Switch

f. Recoil Starter
g. Muffler
h. Spark Plug
i. Air Cleaner

Langkah-langkah dalam melakukan eksperimental dengan mesin motor bakar dengan mainjet nosel yang berbeda adalah :

1. Mengisi bensin pada tangki bensin

2. Membuka keran nomer 1 untuk mengisi labu ukur lalu buka kembali keran nomer 2 untuk mengalirkan bensin menuju ke karburator atur bensin hingga berposisi penuh pada labu ukur yang berukuran $8 \mathrm{ml}$.

3. Pemasangan karburator yang suda siap dipakai dan busi yang baru. Dengan menggunakan kunci ring 10 dan kunci busi.

4. Menyalurkan semua termokopel, tachometer, forcemeter.

5. Menyalurkan air dan buka katub pada pornybrake sedikit demi sedikit dengan pembebanan yang kita suda atur.

6. Menyalurkan mesin dengan posisi on dan tarik engkol pada mesin.

7. Setelah menyala atur bukaan gas menuju rpm yang kita suda sepakati yaitu: 1300,1700 , 2100, 2500, 2900, 3400, 3800.

8. Ambil data laju bahan bakar, gaya, dan suhu pada masing-masing rpm tersebut.

9. Lalu perlahan turunkan putaran mesinnya lalu matikan.

10. Lakukan langkah nomer 2 sampai dengan 8 dengan 2 jenis karburator yang berbeda. 


\section{HASIL DAN PEMBAHASAN}

Analisis Putaran VS Torsi.

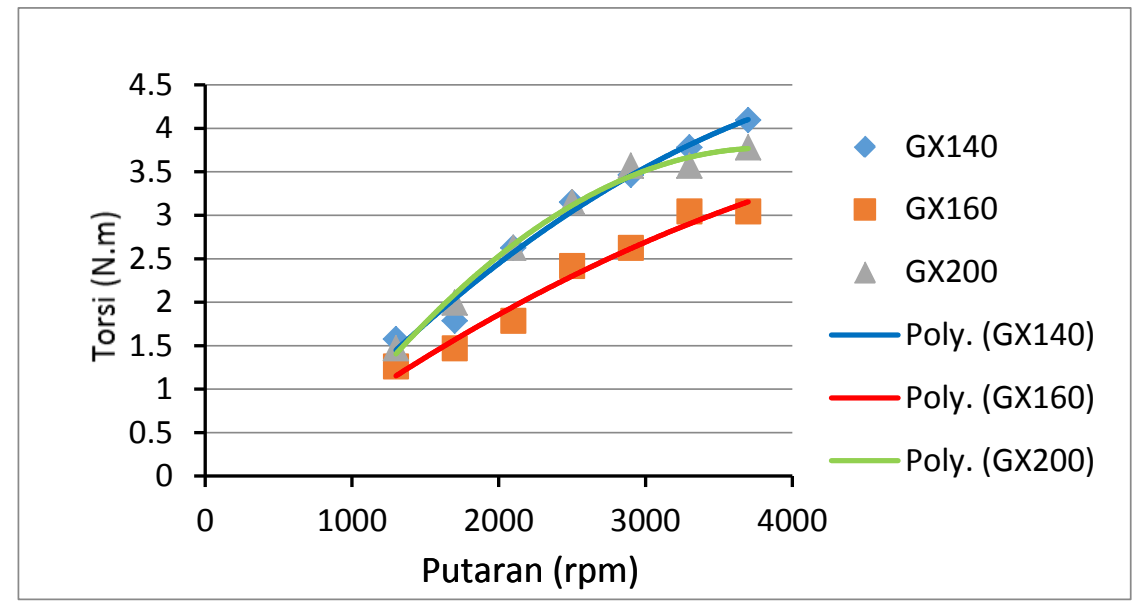

Gambar 8. Putaran VS Torsi

Bahwa torsi yang dihasilkan oleh nosel GX140 lebih besar ketika pada putaran atas dibandingkan dengan nosel GX160 dan nosel GX200. Kecuali pada putaran rendah torsi nosel GX200 lebih tinggi di banding dengan nosel GX140 dan GX160. Torsi yang dihasilkan GX140 dan GX200 semakin meningkat seiring dengan semakin besarnya rpm. Nilai torsi terkecil didapatkan pada 1300 rpm yaitu untuk nosel aslinya GX160 sebesar 1,26 Nm. Sedangkan untuk nilai torsi terbesar didapatkan pada 3700 rpm dimana untuk nosel GX140 didapatkan nilai sebesar 4,095.

Jadi percepatan sudut benda sebanding alias berbanding lurus dengan torsi. Semakin besar torsi, semakin besar percepatan sudut. Semakin kecil torsi, semakin kecil percepatan sudut (percepatan sudut $=$ perubahan kecepatan sudut) [1] .

\section{Analisis Putaran VS BHP.}

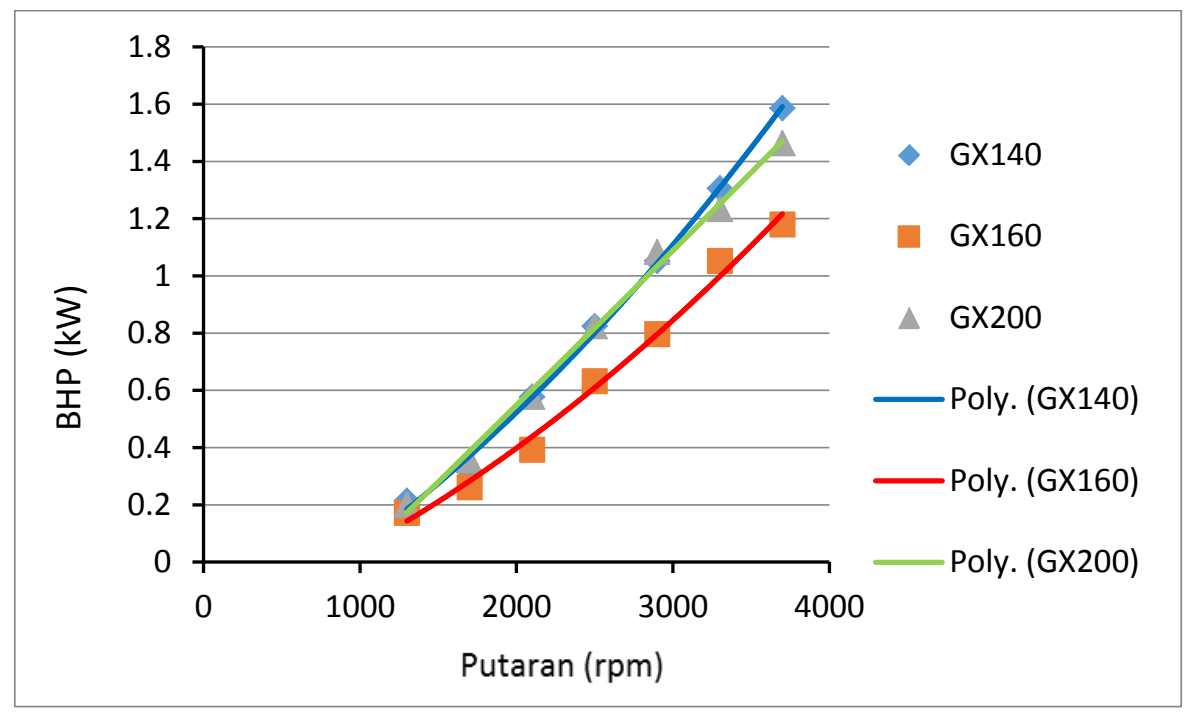

Gambar 9. Putaran VS BHP.

Bahwa daya tertinggi pada putaran mesin 3700 oleh nosel GX140 dengan nilai sebesar $1.585 \mathrm{~kW}$ atau dapat dikatakan mengalami peningkatan hingga 34,43\% dari nosel aslinya GX160. Daya terendah di dapatkan pada rpm 1300 oleh nosel GX160 dengan nilai 1.179 kW namun apa 
bila dibandingkan dengan daya awal nosel GX140 akan mengalami peningkatan dibandingkan dengan nosel aslinya GX160. Peningkatan tersebut senilai 25,14\%.

Secara umum daya berbanding lurus dengan luas piston sedang torsi berbanding lurus dengan volume langkah. Parameter tersebut relatif penting digunakan pada mesin yang berkemampuan kerja dengan variasi kecepatan operasi dan tingkat pembebanan .Daya maksimum didefinisikan sebagai kemampuan maksimum yang bisa dihasilkan oleh suatu mesin. Adapun torsi poros pada kecepatan tertentu mengindikasikan kemampuan untuk memperoleh aliran udara dan juga bahan bakar yang tinggi ke dalam mesin pada kecepatan tersebut. Sementara suatu mesin dioperasikan pada waktu yang cukup lama, maka konsumsi bahan bakar serta efisiensi mesinnya menjadi hal yang sangat penting.[1]

\section{Analisis Putaran VS BSFC.}

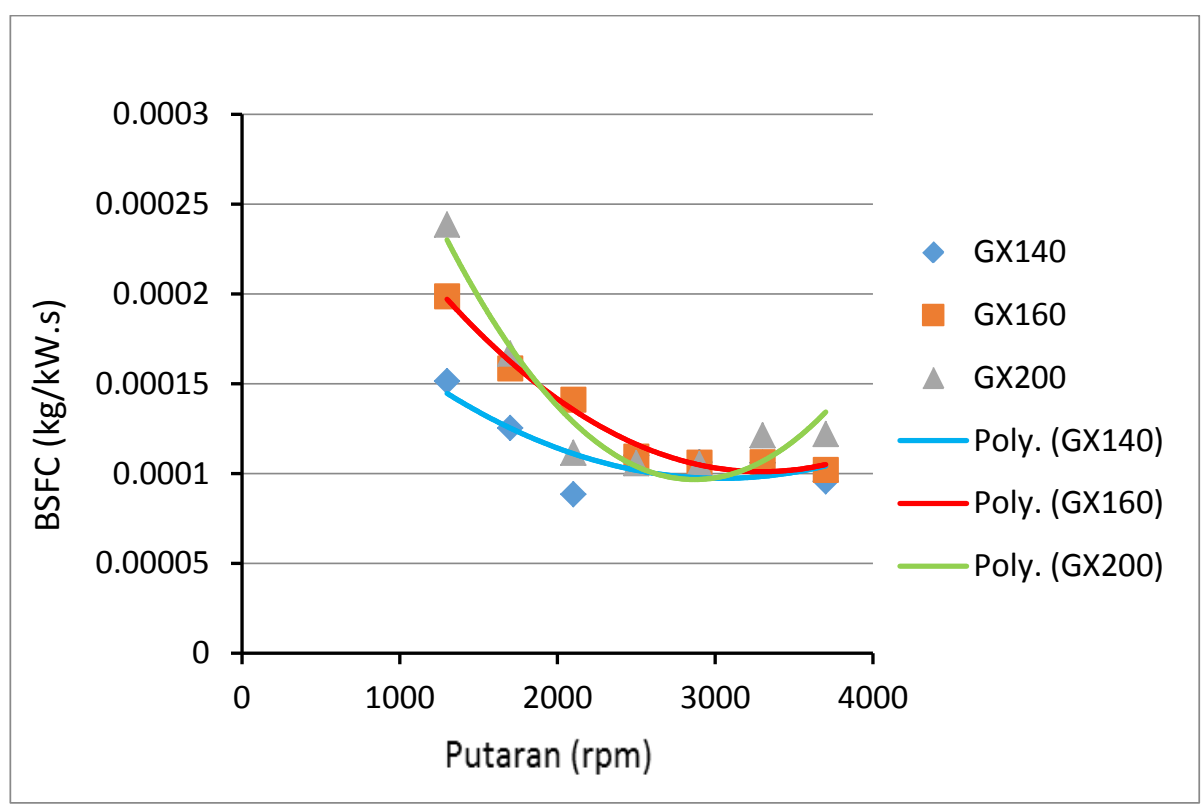

Gambar 10. Putaran vs BSFC.

Pada nosel berpengaruh juga pada laju bahan bakar spesifik pada motor bakar. Laju bahan bakar spesifik paling rendah terjadi pada putaran $3700 \mathrm{rpm}$ dengan nosel yang digunakan yaitu nosel GX140 mendapatkan hasil dengan laju 0,956 x $10^{-4} \mathrm{~kg} / \mathrm{kW} . \mathrm{s}$, atau naik performanya dibanding dengan aslinya nosel GX160 hingga 6,27\%. Berdasarkan teori, setelah melewati torsi maksimum, pembakaran terjadi dalam keadaan kaya dengan menambahnya supply bahan bakar. Berdasarkan teori, setelah melewati torsi maksimum, pembakaran terjadi dalam keadaan kaya dengan menambahnya supply bahan bakar. Akan tetapi pada titik ini, laju bahan bakar tampak turun. Berarti, pengaruh pergantian diameter nosel pada diameter nosel yang lebih kecil dari pada aslinya nosel GX160 memberikan dampak positif pada kinerja mesin dengan daya yang juga meningkat. Perbedaan terjadi pada nosel GX200 nampak nosel GX140 dan GX160 lebih baik dari pada GX200.

Pada analisis kali ini menunjukan nosel GX140 sebagai yang terbaik walau di keadaan 2500 rpm dan 2900 rpm mengalami laju bahan bakar yang sangat cepat sehingga hampir sama dengan nosel GX200 yang diameternya lebih besar dari pada nosel GX160 dan nosel GX140. Tetapi pada tren ini menunjukan tren yang baik juga pada nosel GX140 yang lebih baik dari pada keduanya di salah satu yaitu nosel GX160 nosel aslinya.

Reaksi pembakaran adalah reaksi kimia bahan bakar dan oksigen yang diperoleh dari udara yang akan menghasilkan panas dan gas sisa pembakaran yang berlangsung dalam waktu yang 
sangat cepat. Reaksi pembakaran tersebut akan menghasilkan produk hasil pembakaran yang komposisinya tergantung dari kualitas pembakaran yang terjadi.[5].

Proses pembakaran akan lebih sempurna apa bila pengabutan menghasilkan butiran kecil karena akan lebih mudah terbakar secara baik dan secara kontak area lebih besar penyebarannya. Maka akan di hasilkan pembakaran yang lebih baik pada unjuk kerja mesin motor bakar.[1]

Analisis Putaran VS Efisiensi Termal.

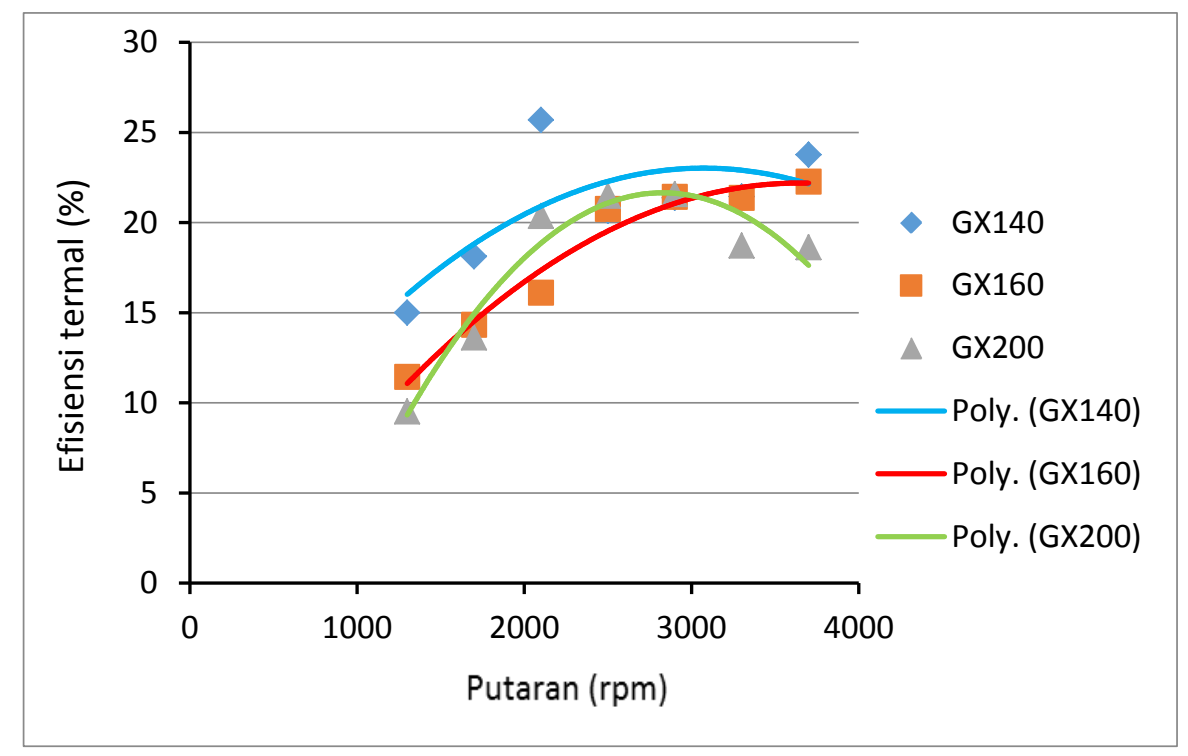

Gambar 11. Putaran vs Efisiensi Termal.

Dari grafik yang telah dibuat. Maka mendapatkan hasil pada putaran $1300 \mathrm{rpm}$ yang paling rendah efisiensi termalnya adalah nosel GX200 dan yang paling baik efisiensinya ialah GX140. Menurut hasil dari percobaan ini menunjukan efisiensi termal tertinggi adalah nosel GX140 dan paling rendah ialah GX200. Nilai dari efisiensi pada putaran $3700 \mathrm{rpm}$ dengan efisiensi tertinggi yaitu 23,76\% dan nilai efisiensi termal pada saat $1300 \mathrm{rpm}$ yaitu 15\%.Sehingga pada performa dan dari akibat penggantian diameter nosel maka berdampak baik juga pada efisiensi termal ini. Tren yang cukup positif di hasilkan oleh nosel pengganti yaitu nosel GX140 dan nosel GX200. Dapat dipastikan bahwa nosel GX140 dinyatakan lebih baik di bandingkan dengan nosel GX160 yaitu nosel aslinya.

Efisiensi termal menyatakan perbandingan antara daya yang dihasilkan terhadap jumlah energi bahan bakar yang diperlukan untuk jangka waktu tertentu. Konsep efisiensi menjelaskan bahwa perbandingan antar energi berguna dengan energi yang masuk secara alamiah tidak pernah mencapai 100\%. [1]

\section{Analisis Putaran VS Temperatur.}

Penggantian diameter nosel pada mesin motor bakar ini tidak berpengaruh tinggi terhadap temperatur yang keluar. Temperatur tertinggi $109^{\circ} \mathrm{C}$ dimiliki oleh nosel GX200 dan nosel GX140 memiliki temperatur yang sama dengan nosel GX160 yaitu $107,5^{\circ} \mathrm{C}$. Sedangkan temperatur terendah di peroleh $60^{\circ} \mathrm{C}$ oleh nosel GX140 dan nosel GX200. Pada nosel GX160 memiliki temperatur terendah $60,5^{\circ} \mathrm{C}$. Kenaikan dan penurunan temperatur yang tidak terlihat jauh antara nosel pengganti dan nosel standarnya maka dapat dikatakan penggantian pada diameter nosel tidak terlalu berpengaruh banyak pada temperatur yang keluar dari motor bakar tersebut ini. Namun data temperatur ini meyakinkan bahwa semakin baik pembakaran maka suhu akan semakin meningkat. 
Apabila pembakaran kaya maka temperatur akan meningkat begitu juga dengan sebaliknya apabila pembakaran miskin maka temperatur tidak setinggi dengan pembakaran kaya serta pembakaran sempurna juga memliki tren temperatur yang meningkat.[5]

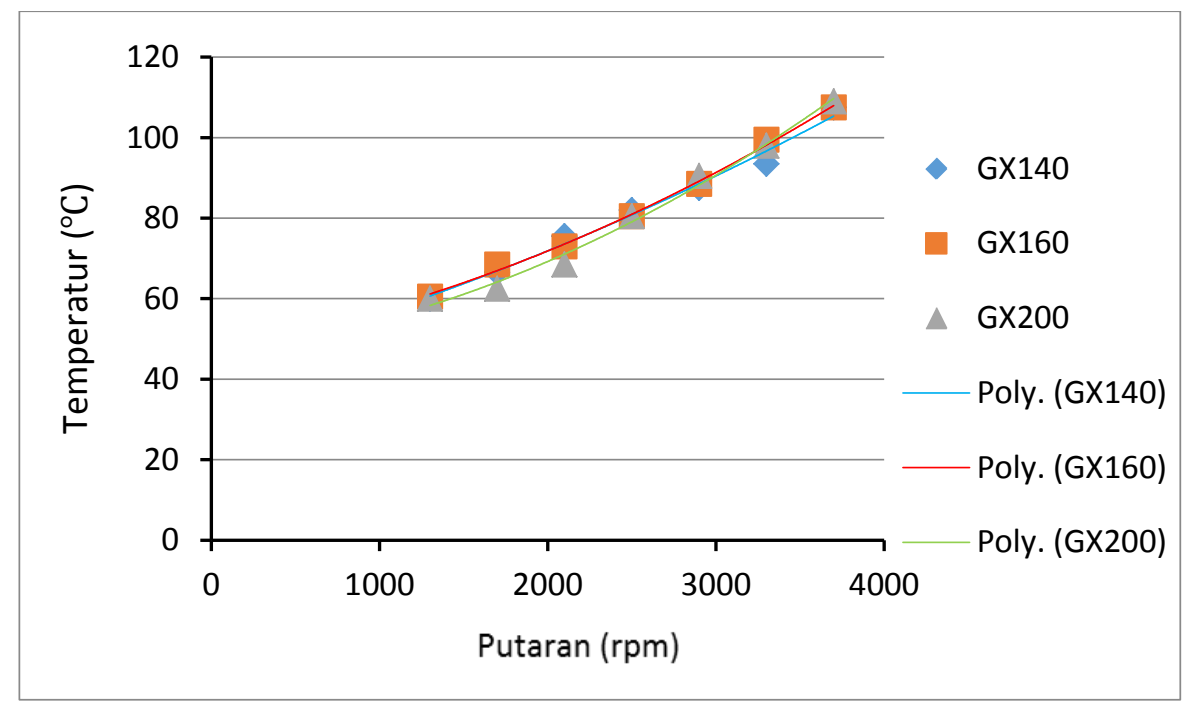

Gambar 12. Putaran vs Temperatur.

\section{KESIMPULAN DAN SARAN}

Dipengujian dengan mesin motor bakar yang menggunakan variasi diameter nosel ini, didapatkan bahwa penggunaan nosel GX140 memiliki peforma yang lebih baik dibandingkan dengan nosel GX160 dan GX200. Hal ini disebabkan karena penggunaan nosel GX140 dengan diameter terkecil menyebabkan proses pengabutan lebih baik karena semakin kecil butiran yang di hasilkan maka pembakaran akan lebih sempurna. Sebab kontak area bahan bakar semakin besar dan membuat penguapan lebih baik. Menggunakan nosel GX140 mendapatkan torsi terbesar dengan nilai 4,095 Nm ketika di posisi 3700 rpm. Sedangkan nosel GX160 dan GX200 tidak mendapatkan torsi sebesar GX140. Penggunaan nosel GX200 tidak menghasilkan yang terbaik karena di nilai dari segi efisiensi yang kurang baik karena laju bahan bakar yang sangat tinggi atau bisa di katakan boros bahan bakar. Meskipun torsi juga di atas dari torsi standarnya tetapi tidak dapat melewati torsi nosel GX140.

Adapun saran yang dapat saya berikan merupaka perbedaan diameter nosel yang membuat unjuk kerja mesin motor bakar menjadi lebih baik. Menggunakan diameter kecil lebih baik dari segi hemat bahan bakar, torsi yang meningkat, serta daya meningkat. Disebabkan butiran kecil yang memudahan proses pembakaran yang menjadi lebih baik. Perlunya pencobaan atau pengujian terhadap mesin tersebut terlebih dahulu tidak semua mesin berkarakteristik sama maka dari itu perlunya menguji diameter lebih besar atau diameter lebih kecil guna untuk mengetahui yang mana yang lebih baik terhadap performa mesin motor bakar tersebut.

\section{DAFTAR PUSTAKA}

[1]. Ganesan. V. Internal Combustion Engine. McGraw-Hill. USA. 1996.

[2]. Jalius Jama, dkk. 2008. Teknik Sepeda Motor. Direktorat Pembinaan Sekolah Menengah Kejuruan: Jakarta.

[3]. Y. A. Cengel and M. A. Boles, Thermodynamics:An Engineering Approach, $5^{\text {th }}$ ed, McGrawHill. 2006.

[4]. AHM Buku Pedoman Reparasi Honda, 2009

[5]. Keating, Eugene. L. Applied Combustion. USA: Marcel Dekker,Inc., 1993

[6]. Haryono,G. Uraian Praktis Mengenal Motor Bakar. Penerbit Aneka Ilmu, Semarang, 1997. 
[7]. Arismunandar, Wiranto. Penggerak Mula Motor Bakar Torak, edisi kelima. Institut Teknologi Bandung, Bandung, 2002.

[8]. Sunyoto,dkk. 2008. Teknik Mesin Industri. Direktorat Pembinaan Sekolah Menengah Kejuruan: Jakarta.

[9]. V.L Malev. Internal Combustion Engine. Mc Graw - Hill Book Company, Singapore, 2008.

[10]. Arends, B. Motor Bensin. Jakarta, Erlangga, 1980. 